\title{
The role of marine salt and surfactants in the decline of Tyrrhenian coastal vegetation in Italy
}

\author{
F Bussotti ${ }^{1}$, P Grossoni ${ }^{1}, \mathrm{~F}$ Pantani ${ }^{2}$ \\ 1 Dept of Plant Biology, Laboratory of Forest Botany, University of Florence, \\ Piazzale delle Cascine, 28, 1-50144 Florence; \\ 2 Dept of Public Health, Epidemiology and Environmental Analytical Chemistry, \\ Section of Analytical Chemistry, University of Florence, via G-Capponi, 7, \\ I-50100 Florence, Italy
}

(Received 22 March 1994; accepted 6 September 1994)

\begin{abstract}
Summary - The decline of coastal vegetation is a phenomenon affecting some areas of the Mediterranean region and Australia; it is due to the presence of surfactants in marine aerosols, a consequence of sea pollution by detergents. This paper gives some observations made at various sites along the Tyrrhenian coast in Italy. The authors show that the presence of surfactants in the environment correlates with the presence of sea salt, and that the impact of surfactants on vegetation is local and occurs only in association with strong sea winds. The study of the synergistic effect of surfactants and sea salt on the crowns of trees exposed to aerosols suggests that the surfactant can cause direct damage, while the absorption of sea salt is enhanced by the presence of the surfactant only when exposure to aerosol is prolonged, or if it is administered in very high concentrations.
\end{abstract}

Pinus pinea L / marine aerosol / surfactant / $\mathrm{NaCl}$ / leaf absorption / crown damage

Résumé - Le rôle du sel marin et des agents tensio-actifs dans le dépérissement de la végétation côtière tyrrhénienne en Italie. Le dépérissement de la végétation côtière est un phénomène qui concerne un certain nombre de zones de la Méditerranée et de l'Australie; il est dû à la présence d'agents tensio-actifs, engendrés par la pollution hydrique de détergents dans les aérosols marins. Notre recherche fait le point de 10 années d'observations d'un certain nombre de localités italiennes du littoral tyrrhénien. II en ressort que la présence d'agents tensio-actifs dans l'environnement dépend de la présence de sel marin ; leur impact sur la végétation est local et il est limité aux périodes de vent de mer fort. L'étude de l'action synergique des agents tensio-actifs et du sel marin sur les houppiers des plantes exposées aux aérosols suggère l'existence d'un dommage direct dû à l'agent tensio-actif en question, tandis que l'absorption de sel marin n'est favorisée par la présence de l'agent tensio-actif que dans des conditions d'exposition prolongée à l'aérosol ou s'il est administré en fortes concentrations.

Pinus pinea L / aérosol marin/ tensio-actifs / $\mathrm{NaCl}$ / absorption foliaire / dommages au houppier 


\section{INTRODUCTION}

Since the early 1960 s the vegetation in a number of coastal areas has been affected by a kind of decline which, in terms of both quality and intensity, is very different from the normal damage caused by salt. In actual fact the spontaneous coastal vegetation has adapted to the action of salt, so that natural marine sprays only cause rather limited damage, consisting primarily of changing the shape of the crown or in the death of external branchlets. More severe damage can be caused occasionally by violent sea storms (Franzén, 1990). The environmental factor usually blamed for this type of decline (besides salt) is the pollution of the sea by synthetic surfactants and oil, ie organic substances that accumulate primarily in the spray.

The first studies on this topic date back to the 1960s (Lapucci, 1968; Gellini and Paiero, 1969; Lapucci et al, 1972) and concentrated primarily on the death of the coastal vegetation in the forest at San Rossore (Pisa), while Gisotti (1979) and Gisotti and De Rossi (1980) studied the conditions of the forest at Castelporziano (Rome). A second set of research studies followed in the $1980 \mathrm{~s}$ (Gellini et al, 1981, 1982, 1983, 1985, 1987; Bussotti et al, 1984; Guidi et al, 1988; Innamorati et al, 1989; Grossoni et al, 1990), also focusing on San Rossore. In the meantime studies were also carried out in Australia (Pitman et al, 1977; Dowden et al, 1978; Grieve and Pitman, 1978; Truman and Lambert, 1978; Dowden and Lambert, 1979; Moodie et al, 1986), in France (Devèze and Sigoillot, 1978; Sigoillot et al, 1981; Sigoillot, 1982; Garrec and Sigoillot, 1992; Badot and Garrec, 1993) and, more recently, in Spain along the coast near Barcelona (Astorga et al, 1993). In all the areas studied the damage is located near urban zones or near wastewater collector tanks and extends inland for a stretch of a few hundred metres or at most $1 \mathrm{~km}$. After especially violent wind storms the damage can occasionally reach zones that are many kilometres from the coast (Grossoni et al, 1990; Raddi et al, 1992). However damage of this type is always extremely localized. According to the majority of the authors mentioned above this damage is primarily due to the fact that the crown absorbs an excess of sea salt, which then accumulates in the leaf tissues. In fact, the damage always appears to be associated with high quantities of $\mathrm{Na}^{+}$and $\mathrm{Cl}^{-}$in the leaves. In coastal species, in normal conditions, the absorption of sea salt is limited by the normal defence mechanisms of the leaves, but in the cases examined here the absorption is enhanced by the presence of surfactants (Greene and Bucovak, 1974). Based on our findings, and also referring to the vast literature that exists on the subject, we cannot rule out that surfactants may exert a direct effect on chloroplasts and other cellular organs (Itoh et al, 1963; Ogawa et al, 1966; Deamer and Crofts, 1967; Helenius and Simmons, 1975) or on the epicuticular wax structures (Gellini et al, 1985; 1987; Noga et al, 1987; Wolter et al, 1988).

The aim of this report is to give the results of some research work carried out over a vast area of the Tyrrhenian coastland in Italy, including the 2 estates belonging to the presidency of the Italian Republic (San Rossore (Pisa) and Castelporziano (Rome)) and the pinewood of Cecina (Leghorn), where severe damage to the vegetation has been observed. The report will also illustrate the results of a number of experiments the aim of which was to measure the toxicity of the various components of polluted sea spray, both in isolation and in synergy.

\section{MATERIALS AND METHODS}

\section{Determination of surfactants and chlorides in sea aerosol}

The determination of surfactants and chlorides (the latter are useful as indicators of the pres- 
ence of sea salt) in aerosols was carried out at San Rossore, Cecina and Castelporziano, primarily in 2 matrices, rainwater and deposits on the vegetation, which normally contain such poliutants when situated near the coast.

Rainwater samples were collected both near the coast and $2-3 \mathrm{~km}$ inland. Samples of bulk deposits were taken from pine trees (Pinus pinea $L$ ) from the section of the crown exposed to the sea and also from the opposite side. Table I shows the characteristics of the different samplings. Rainwater samples were collected on a weekly basis, while the deposits were gathered only after strong sea wind events.

In order to extract the deposits from the surface of the needles, $20 \mathrm{~g}$ of fresh needles, measuring about $12.5-14 \mathrm{~cm}$ in length and giving an overall surface area of about $850 \mathrm{~cm}^{2}$, were rinsed in $200 \mathrm{~cm}^{3}$ deionized water for $20 \mathrm{~min}$. The solutions thus obtained were then analysed.

Anionic surfactants were measured as MBAS (methylene blue active substances), according to Longwell and Manièce's colorimetric method (1955); chlorides were measured by potentiometric titration with $0.1 \mathrm{~N}$ silver nitrate.

Analytical values are given in ppm for raintall and in $\mathrm{mg} / \mathrm{kg}$ of needles (fresh weight) for deposits. The correlation between MBAS and $\mathrm{Cl}^{-}$ in the different matrices was calculated according to Kendall's non-parametric test (rank correlation), and the software used was Statgraphics.

\section{Experimental tests on the toxicity of the aerosols}

Tests were performed by spraying the crowns of young trees of $P$ pinea $L$, Quercus ilex L, Pittosporum tobira $L$ and Acer opalus Mill with solutions containing surfactants and $\mathrm{NaCl}$ in varying concentrations, thus simulating the composition of sea aerosols. The efficacy of this treatment was assessed by ascertaining the percentage of damaged leaves (ie leaves with yellowing) and the quantity of $\mathrm{NaCl}$ absorbed through the leaves shown by the increase of the $\mathrm{Cl}^{-}$ion.

Twenty grams of needles (about 150 needles) from $P$ pinea trees, or 20 leaves from broadleaves, were collected from each treated tree and the same sample was used to calculate both the percentage of damaged needles and the content of $\mathrm{Cl}^{-}$. For each tree, the sampling was repeated twice

In order to measure chlorides in the $P$ pinea needles, the needles were rinsed before testing for about $5 \mathrm{~min}$ in deionized water. The chloride extraction was performed according to the method described by Grieve and Pitman (1978); the analytical method used is potentiometric titration with $0.1 \mathrm{~N}$ silver nitrate. The absorbed salt is expressed as $\mathrm{mg}$ of $\mathrm{Cl}^{-}$per gram of dry matter. The significance of the differences has been tested by Student's $t$ test.

Table I. Sampling characteristics and number of samples gathered.

\begin{tabular}{|c|c|c|c|c|c|}
\hline Location & $\begin{array}{l}\text { Period of } \\
\text { sampling }\end{array}$ & $\begin{array}{r}\text { Rainwater } \\
\text { collected at } \\
\text { the coastline }\end{array}$ & $\begin{array}{l}\text { Rainwater } \\
\text { collected } \\
\text { inland }\end{array}$ & $\begin{array}{l}\text { Deposits on } \\
\text { exposed } \\
\text { needles }\end{array}$ & $\begin{array}{c}\text { Deposits on } \\
\text { sheltered } \\
\text { needles }\end{array}$ \\
\hline
\end{tabular}

San Rossore Nov 1982

May 1983

32

30

45

31

San Rossore $\begin{aligned} & \text { Oct } 1990 \\ & \text { June } 199\end{aligned}$

Castelporziano Mar 1986

Nov 1987

24

0

10

4

Cecina

Oct 1983

Jan 1985
40

20
8 
The following is a description of the tests carried out:

\section{1st experiment - treatment of $P$ pinea in the open field}

The following sets of tests were made:

$-\mathrm{NaCl}$ in varying concentrations $(0,30,60$ and $120 \mathrm{~g} / \mathrm{l}$ );

$-\mathrm{NaCl}$ in a single concentration $(30 \mathrm{~g} / \mathrm{l}) \mathrm{com}$ bined with an anionic surfactant (ABS = alkyl benzene sodium sulphonate) in varying concentrations $(10,50,100,250$ and $500 \mathrm{mg} / \mathrm{l})$;

- ABS in a single concentration (100 mg/l) combined with $\mathrm{NaCl}$ in varying concentrations $(10$, $15,20,30,60$ and $120 \mathrm{~g} / \mathrm{l}$ ).

The experiment was carried out on trees that were about $2 \mathrm{~m}$ high, belonging to a reforested plot within the San Rossore estate. Each test was repeated on 4 different trees; the treatment was repeated twice, in July and in September, and consisted of spraying the crown with a motorized atomizer. Each treatment lasted a few minutes, as long as was necessary to soak the crown to dripping point. Monitoring was done 1 month after the second treatment.

\section{2nd experiment - treatment of $P$ pinea seedlings growing in pots}

The seedlings were sprayed with $\mathrm{NaCl}$ alone $(30 \mathrm{~g} / \mathrm{l})$, with $A B S(500$ and $1000 \mathrm{mg} / \mathrm{l})$ and with non-ionic surfactants (alkyl phenol ethoxylates, Lerolat 40 and Lerolat 300 , which differ by the length of their alkylic chains) at a concentration of $1000 \mathrm{mg} / \mathrm{l}$. The experiment was carried out at the Faculty of Agrarian Studies at the University of Florence, on pot-grown trees measuring about $1.5 \mathrm{~m}$ in height, using a methodology similar to that described above. The trees were sprayed once only, in June, and monitoring was done the following month. Each test was repeated on 4 different trees.

\section{3rd experiment - treatment in the nebulizing chamber}

Tests were done using $\mathrm{NaCl} 30 \mathrm{~g} / \mathrm{l}$, ABS $250 \mathrm{mg} /$, or $\mathrm{NaCl} 30 \mathrm{~g} / \mathrm{l}+\mathrm{ABS} 250 \mathrm{mg} / \mathrm{l}$. Young trees of $P$ pinea, $P$ tobira, $Q$ ilex and $A$ opalus growing in pots ( 5 individuals per species) were sprayed continuously for $4 \mathrm{~h}$ a day for $3 \mathrm{~d}$. The treatment was done in September and the monitoring the following month. This test simulated exposure conditions that are more similar to what occurs in nature.

\section{RESULTS}

\section{Chemical analysis of rainwater sam- ples and deposits}

When interpreting the results of the chemical analysis of rainwater and deposits it is necessary to bear in mind the interactions between the matrix and aerosol composition. For example, in deposits on needles part of the surfactant binds to the epicuticular wax structures since it is lipophilic, and is therefore not removed by rinsing. However part of the chlorides absorbed by the needle are released during rinsing. In the rainwater samples there can be interferences with atmospheric dust and dry deposits of nonmarine origin.

In any case, the highly significant $(P<$ $0.001)$ correlations between MBAS and chlorides (table II) evident in needle deposits and in rainwater samples collected near the coast suggest that both substances originate from the sea. This is also confirmed by the low level of significance between MBAS and chlorides in the rainwater samples collected further away from the coastal area.

Tables III and IV show the levels of concentration of MBAS in rainwater samples and in deposits on needle surfaces. It is interesting to note that most findings are in the lower concentration classes, while there are relatively few high values and they were all recorded during episodes of strong sea winds (cf, Gellini et al, 1987).

The highest value of MBAS in rainwater collected along the coast is $29.2 \mathrm{ppm}$, 
Table Il. Correlation between MABS and $\mathrm{Cl}^{-}$(coefficient $\tau$ of Kendall's non-parametric test), in different matrices and gathering condition.

\begin{tabular}{|c|c|c|c|c|}
\hline Gathering conditions & Number & $\tau$ & $P$ & $M B A S / C r$ \\
\hline Rainwater collected at the coastline & 81 & 0.3021 & $<0.001$ & 0.007 \\
\hline Rainwater collected inland & 64 & 0.2064 & $<0.05$ & 0.001 \\
\hline Deposits on exposed needles & 44 & 0.5431 & $<0.001$ & 0.021 \\
\hline Deposits on sheltered needles & 34 & 0.5925 & $<0.001$ & 0.009 \\
\hline
\end{tabular}

Table III. MBAS content in rainfall.

\begin{tabular}{lrrrr}
$\begin{array}{l}\text { MBAS } \\
\text { concentration } \\
(p p m)\end{array}$ & $\begin{array}{c}\text { Rainwater } \\
\text { collected at } \\
\text { the coastline }\end{array}$ & $\begin{array}{l}\text { Rainwater } \\
\text { collected } \\
\text { inland }\end{array}$ \\
& Number $\%$ & Number $\%$ \\
\hline $0-0.10$ & 39 & 28.9 & 66 & 86.8 \\
$0.11-0.50$ & 37 & 27.5 & 9 & 11.8 \\
$0.51-1.00$ & 15 & 11.1 & 1 & 1.3 \\
$1.01-5.00$ & 34 & 25.2 & 0 & \\
$5.01-10.00$ & 6 & 4.4 & 0 & \\
$>10.00$ & 4 & 2.9 & 0 & \\
& 135 & 100 & 76 & \\
Total & & & &
\end{tabular}

but MBAS concentration levels only reach $1 \mathrm{ppm}$ or above in $32.5 \%$ of cases, and only go above 10 ppm in $2.9 \%$. Inland, MBAS concentrations reach a maximum of 0.9 ppm and only go above $0.1 \mathrm{ppm}$ in $13.1 \%$ of samples. As far as surface deposits are concerned, in needles exposed to the sea the highest value recorded is $514 \mathrm{mg}$ of MBAS per $\mathrm{kg}$ of fresh needles, but the concentration only goes above $50 \mathrm{mg}$ in $18.5 \%$ of samples. In needles from the side of the crown not exposed to the sea the highest concentration of MBAS is $53 \mathrm{mg}$ per $\mathrm{kg}$ of fresh needles, but only $11.7 \%$ of cases have values higher than $10 \mathrm{mg}$.

This trend shows that 'noteworthy events', ie those with the greatest impact
Table IV. MBAS content in deposits on $P$ pinea needles' surface.

\begin{tabular}{|c|c|c|c|c|}
\hline \multirow[t]{2}{*}{$\begin{array}{l}\text { MBAS } \\
\left(m g . k g f w^{-1}\right)\end{array}$} & \multicolumn{2}{|c|}{$\begin{array}{l}\text { Deposits on } \\
\text { exposed } \\
\text { needles }\end{array}$} & \multicolumn{2}{|c|}{$\begin{array}{l}\text { Deposits on } \\
\text { sheltered } \\
\text { needles }\end{array}$} \\
\hline & Number & $\%$ & Number & $\%$ \\
\hline $0-1.00$ & 13 & 16.0 & 21 & 35.0 \\
\hline $1.01-10.00$ & 26 & 32.2 & 32 & 53.3 \\
\hline $10.01-50.00$ & 27 & 33.3 & 7 & 11.7 \\
\hline $50.01-100.00$ & 8 & 9.9 & 0 & 0 \\
\hline$>100.00$ & 7 & 8.6 & 0 & 0 \\
\hline Total & 81 & 100 & 60 & 100 \\
\hline
\end{tabular}

on the system because of the amount of salt and surfactants they transport, occur rather infrequently within the total number of samples examined. Finally, the ratio $\mathrm{MBAS} / \mathrm{Cl}^{-}$is interesting because it varies considerably according to the matrix in which it is measured. There are probably many factors that influence the quantities of these 2 substances (biological, metereological, chemical, physical, etc). The ratio that is most probably the closest to the original ratio in the aerosol is that recorded in the rainwater gathered near the coastline, ie the one closest to the source. Here the $\mathrm{MBAS} / \mathrm{Cl}^{-}$ratio is 0.007 , which is about $1: 143$, similar to that found in aerosols by Gellini et al (1987) and by Loglio et al (1985, 1986, 1987a,b, 1989). 


\section{Experimental reproduction of the damage}

In the 1st experiment $P$ pinea appeared to be quite susceptible to the absorption and accumulation of $\mathrm{NaCl}$. The levels of $\mathrm{Cl}^{-}$in the pine needies are related to the concentration of salt in the solution, whether the solution also contains surfactants (fig $1 \mathrm{~b}$ ) or not (fig 1a). Salt absorption does not appear to be influenced by the presence of the surfactant (the differences between needles treated with and without surfactants are not significant, $P>0.05$ ). There is no correlation between the percentage of damaged needles and level of $\mathrm{Cl}^{-}(P>0.05)$. Conversely, the concentration of the surfactant plays a very important role in the appearance and extent of damage. The differences between tests with surfactants in concentration up to $100 \mathrm{ppm}$ and without are very significant $(P<0.01)$. It is interesting to note that the percentage of damaged needles increases abruptly when the concentrations of ABS are $100 \mathrm{mg} / \mathrm{l}$ or higher (fig 1c).

The damage observed during this experiment consisted of patches of yellow needles. In no case did the treatment reproduce the typical drying of the top of the needle. If we compare these data with those of previous studies (cf, Gellini et al, 1985) we notice that the damage recorded in this experiment can be attributed to the action of the surfactant.

In the 2nd experiment, in which potgrown $P$ pinea were treated with $\mathrm{NaCl}$ and surfactants, the response was more marked (apical drying of needles) with a considerable accumulation of $\mathrm{Cl}^{-}$in the needles at ABS doses of $500 \mathrm{mg} / \mathrm{l}$ (fig 1d). At higher concentrations of the surfactant (in this experiment we also used non-ionic surfactant) the results are more or less identical. Differences between treatments $\mathrm{B}(\mathrm{NaCl}$ without surfactant) and $A$ (control), C, D, E, $\mathrm{F}$ ( $\mathrm{NaCl}$ with surfactants) are significant with $P<0.01$.
In the 3rd experiment (prolonged exposure in a nebulizing chamber) dieback of the apical needles was achieved with an ABS concentration of $250 \mathrm{mg} / \mathrm{l}$ administered with $30 \mathrm{~g} / \mathrm{l}$ of salt, while ABS alone only causes yellowing. The results of this experiment, illustrated in figure 2, also show the different responses to the treatment by the 4 different species tested. $P$ tobira was the most resistant species, while the deciduous broadleaf $A$ opalus suffered the most damage. $P$ pinea and $Q$ ilex gave intermediate responses: the former was more susceptible to surfactants, and the latter to $\mathrm{NaCl}$. In all cases the combination of surfactant plus $\mathrm{NaCl}$ caused the worst damage. At the concentrations and conditions of exposure used in this experiment, the same pathological manifestations as observed in broadleaves (necrosis of the edges) were reproduced.

\section{DISCUSSION AND CONCLUSIONS}

The results obtained confirm the fact that the damage to coastal vegetation caused by marine aerosols polluted with surfactants is fairly limited in both time and space, although it can occasionally produce catastrophic results. In space, the damage is limited because large sea-salt aerosols are rapidly deposited. Apart from exceptionally violent storms the damage only affects the first few hundred metres of vegetation. In time, it appears that aerosols are produced only during some specific events in winter and surfactants in large quantities were detected only in a small percentage of the samples studied. The surfactants in the inland rainwater samples are only found in very low concentrations (always below $1 \mathrm{mg} / \mathrm{l}$ ) and at these levels no synergistic action with either marine salt or other substances of anthropic origin, such as acidity or pesticides, has been demonstrated (Paoletti et 
A. Without ABS

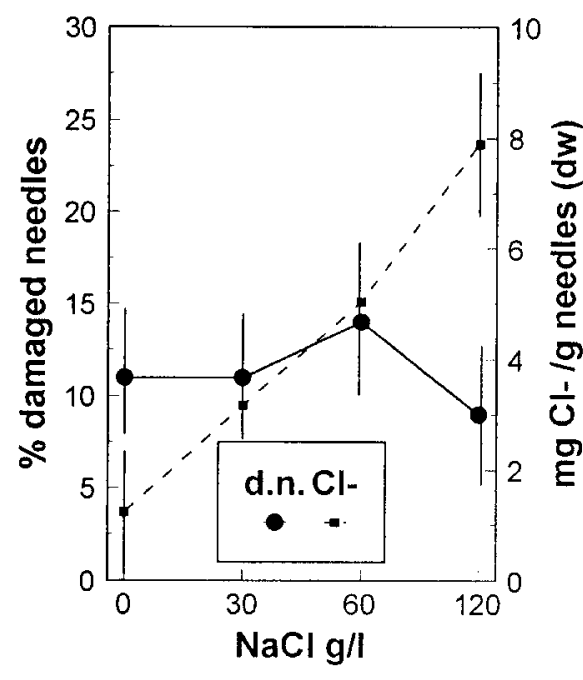

C. $\mathrm{NaCl} 30 \mathrm{~g} / \mathrm{l}$

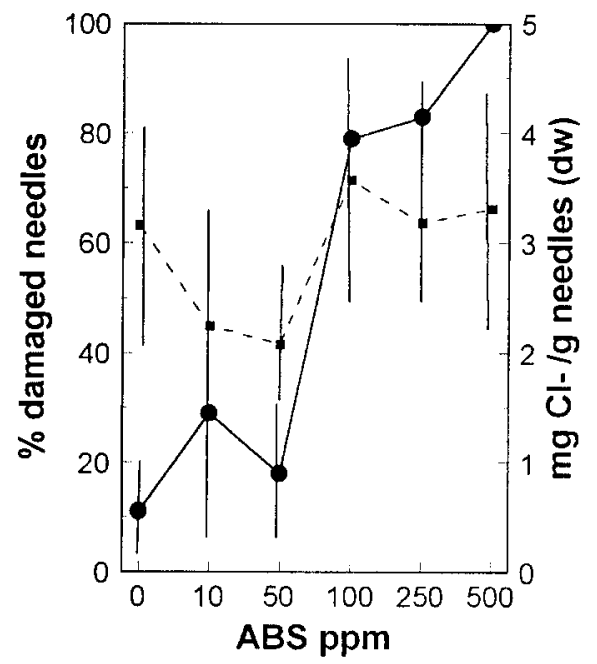

B. ABS $100 \mathrm{ppm}$

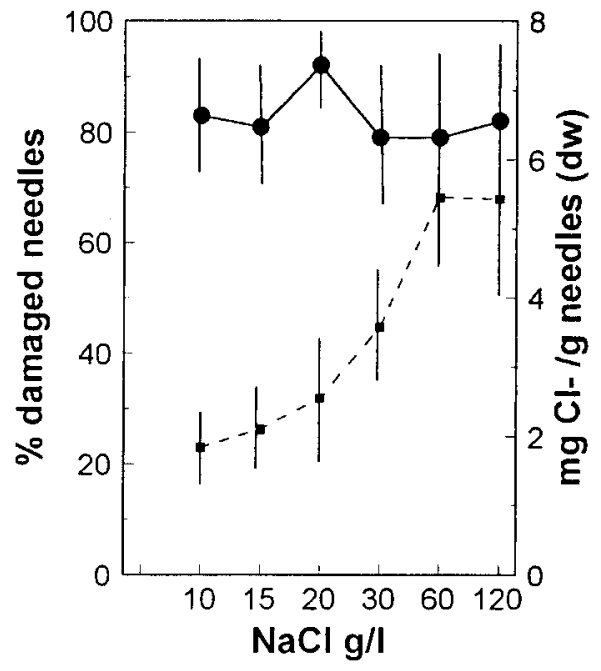

D. Second experiment

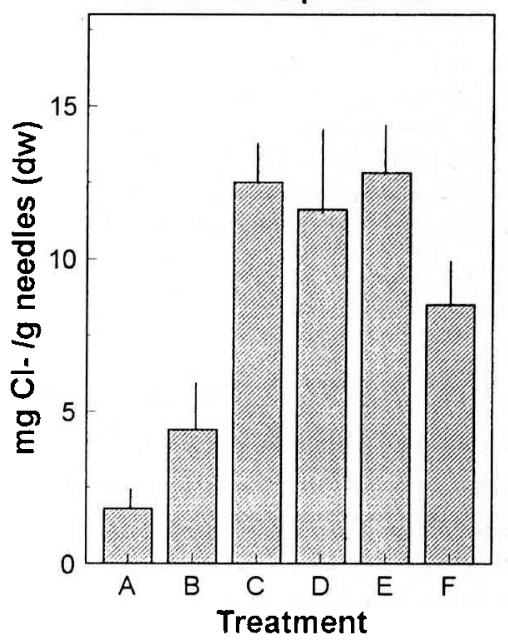

Fig 1. Results of the 1st experiment. A-C: The $\mathrm{Cl}^{-}$concentrations inside the needles and the percentage of damaged needles are indicated on the ordinates. Legend: $\mathrm{dn}=\%$ damaged needles; $\mathrm{Cl}^{-}=$ $\mathrm{mg} \mathrm{Cl} / \mathrm{g}$ needles (dry weight). D: the $\mathrm{Cl}$ - concentrations inside the needles treated in the 2nd experiment: $A=$ control; $B=\mathrm{NaCl}(30 \mathrm{~g} / \mathrm{l}) ; \mathrm{C}=\mathrm{ABS}(500 \mathrm{mg} / \mathrm{l})+\mathrm{NaCl}(30 \mathrm{~g} / \mathrm{l}) ; \mathrm{D}=\mathrm{ABS}(1000 \mathrm{mg} / \mathrm{l})+\mathrm{NaCl}$ $(30 \mathrm{~g} / \mathrm{l}) ; \mathrm{E}=$ Lerolat $40(1000 \mathrm{mg} / \mathrm{l})+\mathrm{NaCl}(30 \mathrm{~g} / \mathrm{l}) ; \mathrm{F}=$ Lerolat $300(1000 \mathrm{mg} / \mathrm{l})+\mathrm{NaCl}(30 \mathrm{~g} / \mathrm{l})$. Bars show standard deviation $(n=8)$. 


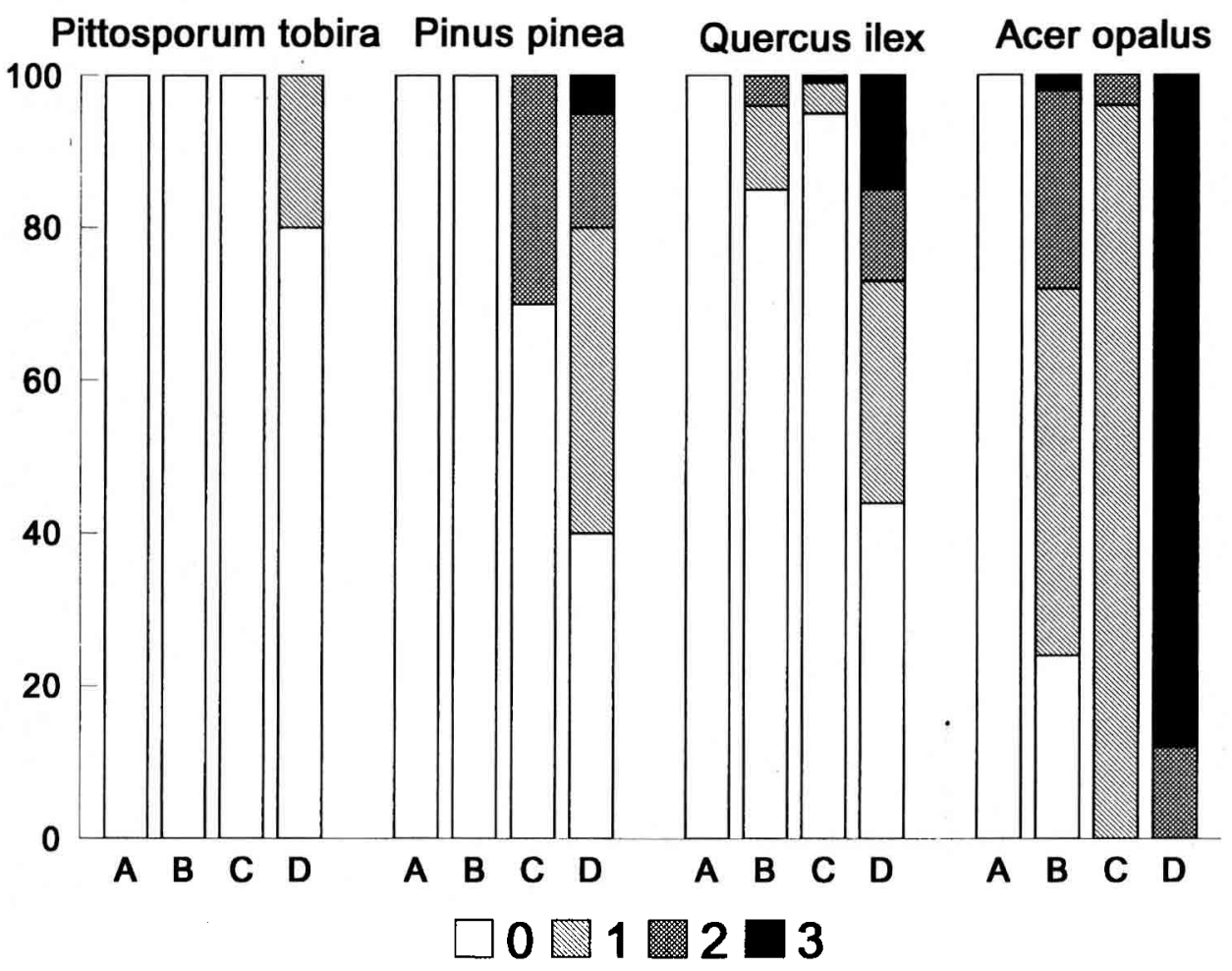

Fig 2. Results of the 3rd experiment, expressed as percentage of damaged leaves divided according to their damage class. The tests are indicated as: $A=$ control; $B=N a C l(30 \mathrm{~g} / /) ; C=A B S(250 \mathrm{mg} / \mathrm{l})$; $\mathrm{D}=\mathrm{ABS}(250 \mathrm{mg} / \mathrm{l})+\mathrm{NaCl}(30 \mathrm{~g} / \mathrm{l})$. The damage classes are indicated as follows: $0=$ no damage; $1=$ extensive damage affecting less than $1 / 3$ of the leaf; 2 = extensive damage affecting between $1 / 3$ and $2 / 3$ of the leaf; $3=$ extensive damage affecting more than $2 / 3$ of the leaf.

al, 1989; Rinallo and Raddi, 1989; Bottacci et al, 1990; Paoletti, 1992).

The experiments performed confirm that the synergy brought about by the combination of surfactants and sodium chloride is the main cause of the decline of coastal vegetation. However, we still need to explain why similar treatments administered to individuals of the same species ( $P$ pinea) have yielded different results ( $c f$ Gellini et al, 1987; Guidi et al, 1988; Loglio et al, 1989). In our opinion these differences are not so much due to genotype differences (the stone pine is a species characterized by a considerable genetic uniformity), but rather to the different stand conditions (trees grown in pots, for example, were more suceptible), vegetational status, macro- and microclimate conditions experienced during the treatment period, as well as treatment modalities.

We would like to stress the following. When the trees were subjected to a treatment consisting of a brief exposure to simulated marine aerosol (1st experiment) the damage they suffered was always less 
severe than when they were subjected to more prolonged exposure (3rd experiment). This last type of treatment is more similar to natural exposure conditions. This observation is also confirmed by the results obtained by Guidi et al (1988) in their 'wind tunnel' experiments. From a practical point of view this means that if we want to reproduce the damage as it appears in nature using only short treatments, we must resort to concentrations that are much higher than those of natural aerosol. Empirically, we can refer to the deposits found on the needles. In order to experimentally obtain deposits that are quantitatively similar to those found in nature we need to spray the crowns with solutions containing at least $1000 \mathrm{mg} / \mathrm{l}$ of surfactant.

The results obtained also highlight the direct action of the surfactant alone, which appears to exert its action before the synergistic effect of surfactant plus salt. This is suggested by the fact that the damage caused by fairly low doses of ABS (1st experiment), even in the presence of salt, are mainly attributable to the surfactant, and there is no correlation between the degree of leaf damage and the $\mathrm{Cl}^{-}$levels in the leaves. Only above a certain level of concentration does the surfactant begin to act synergistically with the salt. In our experiments this threshold appears to be around $250 \mathrm{mg} / \mathrm{l}$ in the case of prolonged exposures, and 500-1 $000 \mathrm{mg} / \mathrm{l}$ for short exposures. Above these thresholds the damage observed is identical to the damage found in nature and is associated with the high content of chloride in the foliar tissues, thus reproducing a type of damage similar to typical salt-induced damage (cfDobson, 1991).

It is interesting to note that the response of $P$ pinea to treatment does not appear to be proportional to the treatment, but rather seems to be influenced by a 'sensitivity threshold'.

Another element which can be useful in understanding our results is the time of year at which treatment was administered. Our experiments, especially those done in the field, were all carried out in the summer, for obvious experimental reasons. Treatments carried out in late autumn and winter, especially surfactant treatments, generally cause less severe damage (our unpublished data), but it is precisely in late autumn and winter that 'normal' exposure to these substances would take place.

Further observations arising from the results of this study concern the toxicity of non-ionic surfactants and the different levels of resistance exhibited by the various species. The results of the 2 nd experiment suggests that (at least at the higher concentrations) non-ionic surfactants also act synergistically with salt, exactly like anionic ones. Since about $30 \%$ of all surfactants available on the market today are non-ionic (Olori and De Fulvio, 1989), it is highly likely that they have a large ecotoxic effect although they are probably not being properly monitored, since we do not possess suitable monitoring methodologies.

Finally, the comparison between the different behaviour of the species tested suggests that resistance to the action of aerosols is the result of the strength of the structures protecting the leaf, and increases with sclerophyllia and with the thickness of the cuticle.

\section{ACKNOWLEDGEMENTS}

The authors would like to thank all those who have worked actively on this research project, and especially E Cenni, R Adversi, A Ceppatelli, M Guglini, V De Cristofaro, C Sequi and G Pistoia. Thanks are also due to technicians $F$ Gigli and $S$ Del Panta for their invaluable assistance and to F Maselli for help with the statistics. We would also like to express all the gratitude we feel for the late R Gellini who originally suggested research studies in this field. 


\section{REFERENCES}

Astorga T, Lopez D, Carazo N, Savé R (1993) Effecto del viento marino en la vegetacion urbana del nuevo litoral Barcelonés. Actas del II Congreso Ibérico SECH, Spain, 539-545

Badot PM, Garrec JP (1993) Dépérissement local du pin d'Alep (Pinus halepensis) le long du littoral méditerranéen. Rev For Fr 45, 134-140

Bottacci A, Ducci F, Gellini R, Tocci AV (1990) The effects of several pollutants on seedlings of different silver fir (Abies alba Mill) provenances of Apennines. Séminaire International sur les Sapins Méditérranéens. Avignon, France, 11-15 June 1990

Bussotti F, Rinallo C, Grossoni P, Gellini R, Pantani F, Cenni $E$ (1984) La moria della vegetazione costiera causata dall'inquinamento idrico. Monti e Boschi6, 47-55

Deamer DW, Crofts A (1967) Action of Triton X-100 on chloroplast membranes. J Cell Biol 33, 395-410

Devèze L, Sigoillot JC (1978) Les arbres malades de la mer. Eau et Aménagement 19, 13-24

Dobson MC (1991) De-icing Salt Damage to Trees and Shrubs. Forestry Commission Bulletin, 101, London, UK

Dowden HGM, Lambert MJ (1979) Environmental factors associated with a disorder affcting tree species on the coast of New South Wales with particular reference to Norfolk Island pines (Araucaria heterophylla). Environ Pollut 19, 71-84

Dowden HGM, Lambert MG, Truman R (1978) Salinity damage to Norfolk Island pines caused by surfactants. II. Effects of sea water and surfactant mixtures on the health of whole plants. Aust J Plant Physiol 5, 386-396

Franzén LG (1990) Transport, deposition and distribution of marine aerorosol over southern Sweden during dry westerly storms. Ambio 19, 180-188

Garrec JP, Sigoillot JC (1992) Les arbres malades de la mer. La Recherche 23, 940-941

Gellini R, Paiero P (1969) Osservazioni preliminari sulle cause del deperimento di alcune pinete litoranee toscane. Boll ing 12, 24-27

Gellini R, Pantani F, Bussotti F, Racanelli E (1981) Sulla degradazione della vegetazione litoranea nella Tenuta di San Rossore. Inquinamento 23, 27 30

Gellini R, Grossoni P, Bussotti F (1982) Stato attuale delle ricerche sul deperimento della vegetazione costiera nelle Tenuta di San Rossore (Pisa). Atti Soc Tosc Sc Nat Mem 89, 319-332

Gellini R, Pantani F, Grossoni P, Bussotti F, Barbolani E, Rinallo C (1983) Survey of the deterioration of the coastal vegetation in the park of San Rossore in Central Italy. Eur J For Path 13, 296-304
Gellini R, Pantani F, Grossoni P, Bussotti F, Barbolani E Rinallo C (1985) Further investigation on the causes of the disorder of the coastal vegetation in the Park of San Rossore (central Italy). Eur J For Path 15 147-157

Gellini R, Pantani F, Grossoni P, Bussotti F (1987) L'influence de la pollution marine sur la végétation côtière italienne. Bull Ecol 18, 213-219

Gisotti G (1979) II deperimento della pineta di Castelfusano. Agricoltura Ambiente, 1. ITPA, Rome, Italy

Gisotti G, De Rossi C (1980) II deperimento della vegetazione litoranea nell'ambito del degrado delle coste italiane. Ing Arch 5-6, 2-14

Greene DW, Bukovac MJ (1974) Stomatal penetration: effect of surfactants and role in foliar absorption. Am $J$ Bot 100-106

Grieve AM, Pitman MG (1978) Salinity damage to Norfolk Island pines caused by surfactants. III. Evidence for stomatal penetration as the pathway of salt entry to leaves. Aust J Plant Physiol 5, 397-413

Grossoni P, Bussotti F, Pantani F, Cini R, Gellini R (1990) Decline of Pinus pinea by polluted marine aerosols. Expertentagung Waldschadensforschung im östlichen Mitteleuropa und in Bayern. Passau, GSF, Neuherberg, 436-440

Guidi L, Lorenzini G, Soldatini GF (1988) Phytotoxicity of sea-water aerosols on forest plants with special reference to the role of surfactants. Environ ExptI Botany, 28, 85-94

Helenius A, Simmons K (1975) Solubilization of membranes by detergents. Biochim Biophys Acta 415 , 29-79

Innamorati M, Mori G, Rossi A, Maselli F (1989) Aerosol marino e tensioattivi nella degradazione della pineta litoranea tra l' Arno ed il Serchio. Atti $3^{\circ}$ Congr Naz $S$ It E Zora Pub, Parma, Italy, 7, 501-505

Itoh M, Izawa S, Shibata K (1963) Disintegration of chloroplasts with dodecylbenzene sulfonate as measured by flattening effect and size distribution. Biochim Biophys Acta 69, 130-142

Lapucci PL (1968) Sull'inquinamento chimico dell'acqua di mare quale causa dei danni alle pinete costiere tirreniche. Rivista Italiana di Igiene $28,589-597$

Lapucci PL, Gellini R, Paiero P (1972) Contaminazione chimica dell'acqua di mare quale causa di moria dei pini lungo le coste tirreniche. Ann Acc It Sci For 21, 323-358

Loglio G, Tesei U, Mori G, Cini R, Pantani F (1985) Enrichment and transport of surfactants in marine aerosol during particular weather conditions. I Nuovo Cimento 8C, 704-713

Loglio G, Tesei U, Marilli G, Cini R (1986) The role of surfactants in coastal sea pollution. Mar Pollut Bull 17, 466-468

Loglio G, Tesei U, Jeraci G, Marilli G, Ricci C, Cini R (1987a) Aspetti chimico-fisici nella formazione, arric- 
chimento e trasporto di materiale particolato nell'ambiente marino. Atti $3^{\circ}$ Congr Naz S It E Zora Pub, Parma, Italy

Loglio G, Tesei U, Marilli G, Ricci C, Jeraci G, Cini R (1987b) Evidenza del trasporto di materiale tensioattivo di natura antropica nell'aerosol marino. Atti $3^{\circ}$ Congr Naz $S$ it E, Zora Pub, Parma

Loglio G, Degli Innocenti N, Gellini R, Pantani F, Cini F (1989) Detergents as a condition of pollution from a coastal marine aerosol. Marine Poll Bull 20, 115-119

Longwell J, Maniece WD (1955) Determination of anionic detergents in sewage effluents and river water. Analyst $80,167-171$

Moodie EG, Stewart RS, Bowen SE (1986) The impact of surfactants on Norfolk Island pines along Sydney coastal beaches since 1973. Environ Poll 41, 153-164

Noga GJ, Knoche M, Wolter M, Barthlott W (1987) Changes in leaf micromorphology induces by surfactants application. Angew Botanik 61, 521-528

Ogawa T, Obata F. Shibata K (1966) Two pigment proteins in spinach chloroplasts. Biochim Biophys Acta $112,223-234$

Olori L, De Fulvio S (1989) I tensioattivi: le tecnologie, i coadiuvanti, la biodegradazione, le normative. Inquinamento 5, 51-53

Paoletti E (1992) Effects of acidity and detergents on in vitro pollen germination and tube growth in forest tree species. Tree Physiol 10, 357-366
Paoletti E, Gellini R, Barbolani E (1989) Effects of acid fog and detergents on foliar leaching of cations. Water Air and Soil Pollution 45, 49-61

Pitman MG, Dowden HGM, Humphrys FR, Lambert MJ, Grieve AM, Scheltema GH (1977) The outfall connection. Aust J Nat Hist 19, 73-81

Raddi P, Moricca S, Gellini R, Di Lonardo V (1992) Effects of natural and induced pollution on the leaf wax structure of three cypress species. Eur J For Path 22, 107-114

Rinallo C, Raddi P (1989) Effects of simulated acid rain and $A B S$ of some broadleaf seedlings. Eur $J$ For Path 19, 151-160

Sigoillot JC (1982) Les aérosols marins en Méditerranée. Doctoral thesis, Univ Aix-Marseille 3, France

Sigoillot JC, Nguyen MH, Devèze L (1981) Pollution par les aérosols marins dans les lles d'Hyères. Trav Sci Parc Nat Port Cros Fr, 7, 45-54

Truman L, Lambert MJ (1978) Salinity damage to Norfolk Island pines caused by surfactants. I. The nature of the problem and effect of potassium, sodium and chloride concentration on uptake by roots. Aust $J$ Plant Physiol 5, 377-385

Wolter M, Barthlott W, Knoche M, Noga GJ (1988) Concentration effects and regeneration of epicuticular waxes after treatment with Triton $X-100$ surfactant. Angew Botanik 62, 53-62 